Nereis. Revista Iberoamericana Interdisciplinar de Métodos, Modelización y Simulación
12

99-108

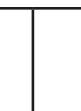

Valencia

(España)

\title{
Isolation and characterization of extracellular vesicles in Candida albicans
}

\author{
Aislamiento y caracterización de las vesículas extracelulares en Candida albicans
}

Fecha de recepción y aceptación: 21 de abril de 2020, 24 de abril de 2020

DOI: $10.46583 /$ nereis_2020.12.611

\author{
Virginia Pérez-Doñate ${ }^{1,2 *}$, Facundo Pérez-Giménez ${ }^{5}$ Lucas del Castillo Agudo ${ }^{1}$, Juan Alberto \\ Castillo-Garit ${ }^{3,4}$, Mar Soria-Merino ${ }^{6}$ y Eulogio Valentín Gómez ${ }^{1}$ \\ ${ }^{1}$ Grupo de Investigación GMCA. Departamento de Microbiología. Facultad de Farmacia. Universitat de Valencia. \\ ${ }^{2}$ Servicio de Microbiología. Hospital Universitario de la Ribera. Alzira. Valencia. \\ ${ }^{3}$ Unidad de Toxicología Experimental. Universidad de Ciencias Médicas de Villa Clara. Santa Clara. Cuba. \\ ${ }^{4}$ Unidad de Investigación de Diseño de Fármacos y Conectividad Molecular. Departamento de Química Física. Facultad \\ de Farmacia. Universitat de València. \\ ${ }^{5}$ Unidad de Investigación de Radiofarmacia y Estabilidad de Medicamentos. Departamento de Química Física. Facultad \\ de Farmacia. Universitat de València. \\ ${ }^{6}$ Servicio de Radiofarmacia. Hospital Clínico Universitario de Valencia. \\ ${ }^{*}$ Correspondencia: Servicio de Microbiología. Hospital Universitario de la Ribera. Ctra. Corbera, km 1, 46600 (Alzira), Valencia. \\ Spain.E-mail: perez_virdon@gva.es
}

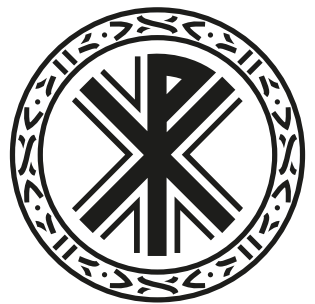

ABSTRACT

Background: The occurrence of systemic infections due to C. albicans has increased especially in critically ill patients. In fungal infections, secretory mechanisms are key events for disease establishment. Recent findings demonstrate that fungal organisms release many molecular components to the extracellular space in extracellular vesicles.

Aims: We develop a method to obtain exosomes from yeast cultures of the Candida albicans. Methods: Yeast strains used in this work were C. albicans SC5314, C. parapsilosis (ATCC 22019) and C. krusei (ATCC 6258). Yeasts were grown at 37. ${ }^{\circ}$ in liquid YPD medium. The cell cultures were centrifuged and the supernatant filtered through sterile nitrocellulose. Filtrates were concentrated and centrifuged using an ultracentrifuge. The sediment was analyzed by electron microscopy of transmission.

Results: The transmission of electron microscopy and nanoparticle tracking analysis confirmed the presence of extracellular vesicles (exosomes) of sizes between 100 and $200 \mathrm{~nm}$ and the absence of cellular contaminants. This was ratified by the characterization of proteins performed through the western blot technique, where the absence of cell contamination in the preparations was assessed.

Conclusions: The method proves to be highly effective due to the homogeneity and purity of the obtained microvesicles. The protocol developed in this paper proves to be effective for obtaining exosomes of other Candida species, which will allow future studies to determine its protein composition and the role that these vesicles can play.

KEYWORDS: exosomes, extracellular vesicles, Candida albicans, tetraspanins. 


\section{RESUMEN}

Contexto: La aparición de infecciones sistémicas por C. albicans ha aumentado sobre todo en pacientes graves. En las infecciones fúngicas, los mecanismos de secreción son eventos clave para que el establecimiento de la enfermedad. Hallazgos recientes demuestran que los organismos fúngicos liberan muchos componentes moleculares al espacio extracelular en vesículas extracelulares.

Objetivos: Desarrollamos un método para obtener exosomas de cultivos de levadura de Candida albicans.

Métodos: Las cepas de levadura que se usaron en este trabajo son C. albicans SC5314, C. parapsilosis (ATCC 22019) y C. krusei (ATCC 6258). Las levaduras se cultivaron a $37 .{ }^{\circ} \mathrm{C}$ en un medio YPD líquido. Los cultivos de células fueron centrifugados y el sobrenadante, filtrado por medio de nitrocelulosa estéril. Los filtrados se concentraron y centrifugaron usando una ultracentrifugadora. El sedimento fue analizado por un microscopio electrónico de transmisión.

Resultados: La microscopía electrónica de transmisión y el análisis de nanopartículas confirman la presencia de vesículas extracelulares (exosomas) de un tamaño entre 100 y $200 \mathrm{~nm}$, así como la ausencia de contaminantes celulares. Esto se ratificó mediante la caracterización de proteínas obtenidas por medio de la técnica de Western blot, donde se evaluó la ausencia de contaminación celular en las preparaciones.

Conclusiones: El método es altamente eficaz dada la homogeneidad y la pureza de las microvesículas obtenidas. El protocolo desarrollado en este artículo demuestra ser efectivo para obtener exosomas de otras especies Candida, lo que permitirá que en futuros estudios se determine su composición proteica y el papel que estas vesículas pueden desempeñar.

PALABRAS CLAVE: exosomas, vesículas extracelulares, Candida albicans, tetraspaninas.

\section{INTRODUCTION}

Candida albicans, a polymorphic fungus with yeast and mycelia as predominant morphological forms, is an opportunistic pathogenic; the increase of immunodeficiency patients of different etiologies has caused a significant rise in the incidence of systemic infection caused by this fungus. Although $C$. albicans is usually found in human microbiome, in healthy individuals $C$. albicans generally remains benign as commensal, although it can occasionally cause a variety of infections, ranging from superficial relatively mild infections of skin or mucosa, to potentially deadly systemic infections. The occurrence of systemic infections due to C. albicans has increased especially in critically ill patients as a consequence of increasing immune-deficiencies of different origins, such as AIDS, antitumor treatment or therapeutic immune suppression in transplant patients [1-9].

The potential of $C$. albicans to infect different host niches is sustained by various virulence factors such as morphological transition between yeast and hyphal forms, the expression of adhesins and invasins on the cell surface, thigmotropism, the formation of biofilms, phenotypic switching and the secretion of hydrolytic enzymes (proteases, phospholipases and lipases) [10]. In fungal infections, secretory mechanisms are key events for disease establishment [11-13] and virulence of C. albicans could be associated with some secretion mechanism. Recent findings show that fungal organisms release many molecular components to the extracellular space in extracellular vesicles (EV) [13-16]. 
Exosomes were discovered nearly 30 years ago, secreted by most cell types and being considered as simple garbage containers to transport non-desired components outside the cell. However, increasing evidence presented these containers as vehicles of information from cell to cell and tissues, altering the function and physiology of the receiver, and being implicated in tissue repair, neural communication or transfer of virulence factors in pathogenesis [17].

Eukaryotes protein secretion is driven by a signal peptide that directly secreted proteins through endoplasmic reticulum and Golgi with a concomitant protein glycosylation. However, the presence of non-glycosylated proteins lacking signal peptide outside the cell has remained unknown. Recently, lots of evidence demonstrated that cells produce vesicles that traverse the cell surface to release a wide range of cellular components into the extracellular space. Yeast cells also produce exosomes like vesicles that can play different roles in intercellular communication and are the vehicles for secretion of non-signal peptides and proteins [18].

Exosomes could play a role in infection by $C$. albicans, identify the components involved in the process, and it might help elucidate possible therapeutic targets and develop potential vaccines or immunotherapy against this infection. In this context, to know the molecules transported by Candida exosomes could bring important information about their potential role in Candida spp. infections. The main aim of this work was to develop a highly effective method for obtaining exosomes of C. albicans with a high degree of purity and free of cellular contamination and to show the possibility of extending the method to other Candida species.

\section{MATERIALS AND METHODS}

\section{Strains, media and growth conditions}

Yeast strains used in this work were C. albicans SC5314, C. parapsilosis (ATCC 22019) and C. krusei (ATCC 6258). Yeasts were grown at $37^{\circ} \mathrm{C}$ in liquid YPD medium $(1 \%$ of yeast extract, $2 \%$ of peptone, and $2 \%$ of glucose). Three flasks of one liter YPD medium were inoculated with 1 $\mathrm{ml}$ from previous $5 \mathrm{ml}$ pre-culture inoculated with an isolated colony. Cultures were incubated in an orbital shaking $(150 \mathrm{rpm})$ at $37^{\circ} \mathrm{C}$ for 48 hours.

\section{Obtaining yeast-free supernatant}

Three liters of cell cultures were centrifuged at 4000xg for $15 \mathrm{~min}$ and supernatant filtered through sterile nitrocellulose, $0.45 \mu \mathrm{m}$ pore size, membrane filters (Sartorius ${ }^{\circledR}$ ).

Filtrates were concentrated by two hours of crossflow filtration using a Sartorius Vivaflow ${ }^{\circledR}$ 50R with an input stream of 200 to $400 \mathrm{~mL} / \mathrm{min}$ and a pressure output of 2.5 bar, obtaining a final volume of $50 \mathrm{~mL}$, which was subjected to a further filtration through pore size of $0.20 \mu \mathrm{m}$ (Sartorius ${ }^{\circledR}$ ) membrane sterile filters to ensure sterility and absence of other cellular elements but exosomes in the sample. 


\section{Ultracentrifugation}

Concentrated filtered samples were centrifuged at 200000xg for $2 \mathrm{~h}$ at $4{ }^{\circ} \mathrm{C}$, using an ultracentrifuge Beckman Coulter Optima ${ }^{\circledR}$ MAX. Sediment was suspended in PBS buffer (Phosphate Buffer Saline: $\mathrm{Na}_{2} \mathrm{HPO}_{4}$ and $\mathrm{KH}_{2} \mathrm{PO}_{4} 0.01 \mathrm{M} ; 0.138 \mathrm{M} \mathrm{NaCl} ; 0.0027 \mathrm{M} \mathrm{KCl}$ ) pH 7.4, to a final volume of 1 $\mathrm{mL}$. Aliquots of $100 \mu \mathrm{L}$ were taken and kept frozen at $-30^{\circ} \mathrm{C}$. One aliquot was processed immediately without freezing, adding $400 \mu \mathrm{L}$ of Karnovsky solution ( $2.5 \%$ paraformaldehyde and glutaraldehyde $0.5 \%$ in PBS buffer), and processed by an electron microscopy of transmission.

\section{Obtaining yeast cellular extracts}

Yeast cells from $1 \mathrm{~mL}$ of YPD liquid culture were collected by centrifugation ( $8000 \mathrm{xg}, 10 \mathrm{~min}$ ). Then they were washed with sterile PBS buffer containing $1 \mathrm{mM}$ of phenylmethylsulfonyl fluoride (PMSF), and re-suspended in $0.5 \mathrm{~mL}$ PBS-PMSF. After that they were dispensed in $2 \mathrm{~mL}$ tubes, the same volume of glass beads (425-600 $\mu$ m of diameter, Sigma $\left.{ }^{\circledR}\right)$ were added and subjected to four $20 \mathrm{~s}$ agitation cycles in a FastPrep FP120 cell disruptor. Cell extract was recovered, centrifuged at 8000xg for 10 minutes and divided in $100 \mu \mathrm{L}$ aliquots and stored frozen.

\section{Protein quantification}

Quantification was carried out using the method of Bradford [19] and the reagent provided by Bio-Rad®.

\section{Transmission electron microscopy (TEM)}

Exosome pellets were fixed with $2.5 \%$ of glutaraldehyde and washed with distilled water. After that, Exosomes were post fixed with $2 \%$ of osmium tetroxide and dehydrated in increasing concentrations of ethanol. Embedding was performed with LR-White resin at $60^{\circ} \mathrm{C}$ for $24-48 \mathrm{~h}$. Ultrathin sections were contrasted with $2 \%$ of uranyl acetate and observed in a JEM 1010 TEM (JEOL) electron microscope at $60 \mathrm{kV}$.

\section{Exosomes size determination}

The size distribution of exosomes was measured using NanoSight LM10 (Malvern, Worcestershire, UK) and analyzed with the Nanoparticles Tracking Analysis software (Malvern) according to the manufacturer's protocol. Before each experiment, the machine was calibrated for nanoparticle size and quantity using standardized nanoparticle dilutions provided by the manufacturer. 


\section{Protein gel electrophoresis and Western blot techniques}

SDS-PAGE electrophoresis was performed as described elsewhere [20] in $10 \%(\mathrm{w} / \mathrm{v})$ acrylamide gels loaded with $20 \mu \mathrm{g}$ protein. The gels were stained with Coomassie brilliant blue or electro-blotted onto polyvinylidene difluoride (PVDF) membrane and immune detected with antibodies anti-Calnexin, anti-CD9, anti-CD63, anti-CD81, anti-Enolase, anti-Hsp70 (System Biosciences, with a dilution of 1:2500) and anti-candida cell wall (our group). Detection was carried out with peroxidase marked goat anti-rabbit antibodies (Sigma-Aldrich, with dilution 1:20000) by the enhanced chemiluminescent (ECL) method from Amersham Biosciences, following the manufacturer's instructions [21,22].

\section{Treatment with Concanavalin A-ferritin}

Each sample, with the sediment containing the exosome fraction, was resuspended in a solution composed of $0.6 \mathrm{M} \mathrm{KCl}, 0.5 \mathrm{M} \mathrm{NaCl}$ and $2 \mathrm{mM}$ in $\mathrm{MnCl}_{2}, \mathrm{MgCl}_{2}$ and $\mathrm{CaCl}_{2}$ (solution A), subsequently adding Concanavalin A-ferritin to a final concentration $0.5 \mathrm{mg} / \mathrm{mL}$ and incubating for $30 \mathrm{~min}$ at room temperature. Each sample was washed twice with solution A, using ultracentrifugation at $200000 \mathrm{xg}$ for $70 \mathrm{~min}$ at $4{ }^{\circ} \mathrm{C}$, both times. The sediment obtained was resuspended with PBS buffer $\mathrm{pH} 7.4$ and fixed with formaldehyde/glutaraldehyde for inclusion in resins and subsequent processing for observation by transmission electron microscopy.

\section{RESULTS AND DISCUSSION}

Samples of exosomes obtained from C. albicans SC5314 were subjected to an analysis of determination of the total protein value, obtaining $0.166 \mu \mathrm{g} / \mu \mathrm{L}$.

To check the purity of the sample a fraction of exosomes was processed by transmission electronic microscopy. Figure 1(A) shows two exosomes from C. albicans SC5314, in which there are vesicular structures with characteristic double membrane, sizes ranging from 100 to $200 \mathrm{~nm}$. Figure 1(B) shows a preparation of exosomes not filtered through a $0.20 \mu \mathrm{m}$ pore size, membrane filters, in which one can see exosome structures mixed with some yeast cells.

The images obtained by transmission electron microscopy have allowed us to validate the method of obtaining exosomes, ratifying the purity of the preparations with double membrane extracellular vesicles with sizes between 100 and $200 \mathrm{~nm}$. Similar results were obtained with yeast cultures of $C$. krusei and C. parapsilosis, which proves the validity of this method to obtain samples of purified microvesicles without cellular contamination (figures 1C and 1D). 

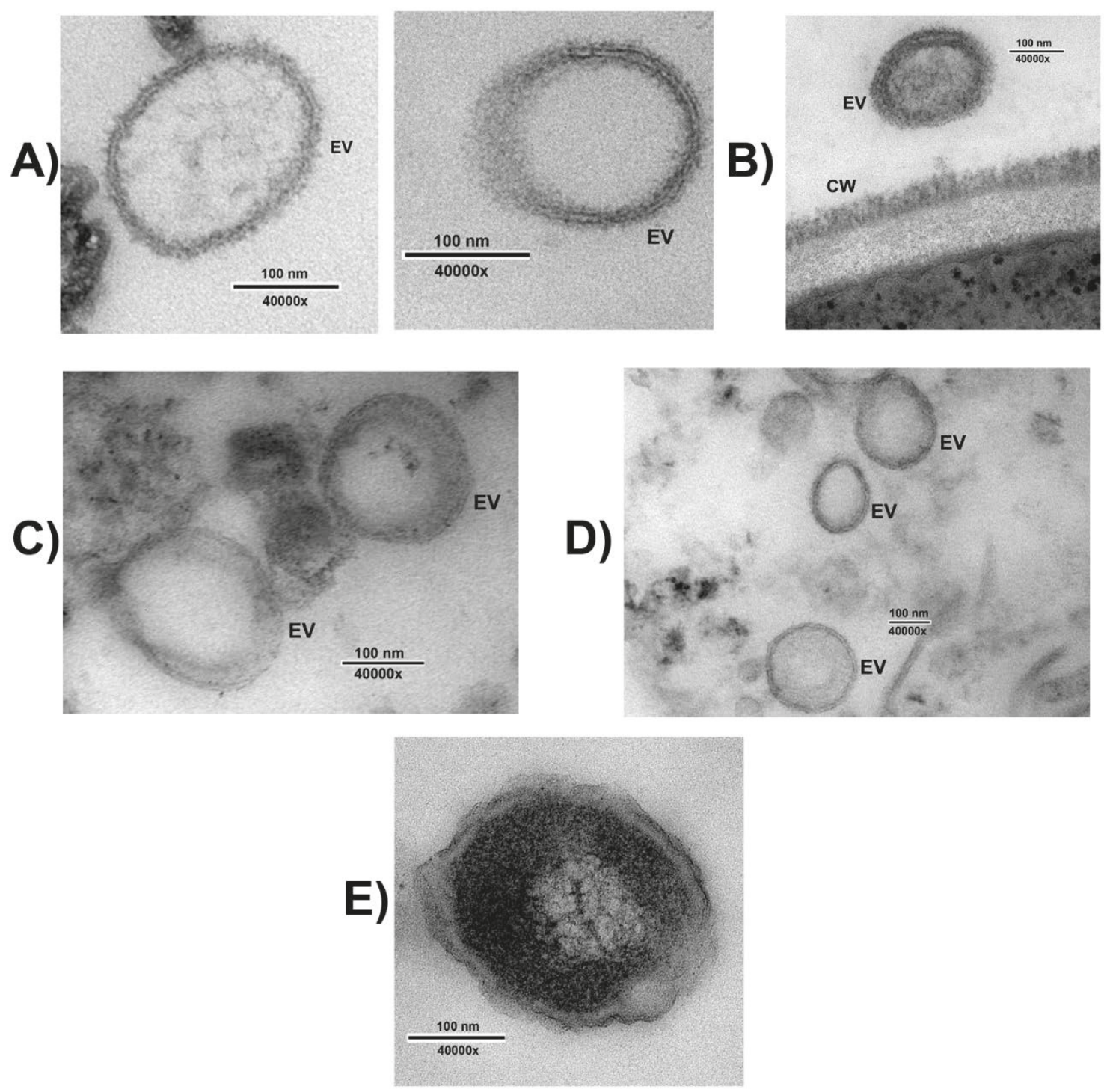

Fig. 1. Images obtained by transmission electron microscopy: (A) Extracellular vesicles of C. albicans SC5314 purified. (B) Exosomes together with yeasts in samples not filtered by $0.20 \mu \mathrm{m}$. (C) Extracellular vesicles of C. krusei and C. parapsilosis (D). (E) Purified exosomes of C. albicans SC5314 without treatment with Concanavalin A-ferritin.

C. albicans SC5314 exosomes' size and purity were evaluated in a Nano Team Sight ${ }^{\circledR}$, by NTA. This technique allows us to determine the size and distribution of particles. The results highlight the high homogeneity of particle sizes. The highest concentrations of particles were those corresponding to the sizes of $125 \mathrm{~nm}$ and $165 \mathrm{~nm}, 146.1 \mathrm{~nm}$ being their average size. A presence of particles with size of 245 and $385 \mathrm{~nm}$ was observed, but they were not taken into account due to their low number. These results corroborate the efficacy of the method to obtain exosomes of high purity. 
Exosome purity was evaluated by Western Blot (WB), using antibody against extracellular vesicles and markers of cytosolic fraction. Figure 2(A) shows the presence of vesicle markers CD9, CD63 and CD81 antigens epitopes in the fractions of exosomes, while reaction is negative in their respective cell lysates (L); on the other hand, cytoplasm marker calnexin was only detected in cell lysate. Moonlighting proteins were also identified in microvesicles, as one can see in Figure 2(B), enolase was only detected in microvesicles, while HSP70 was detected in both microvesicles and supernatant $(\mathrm{SN})$ of the last ultracentifugation.

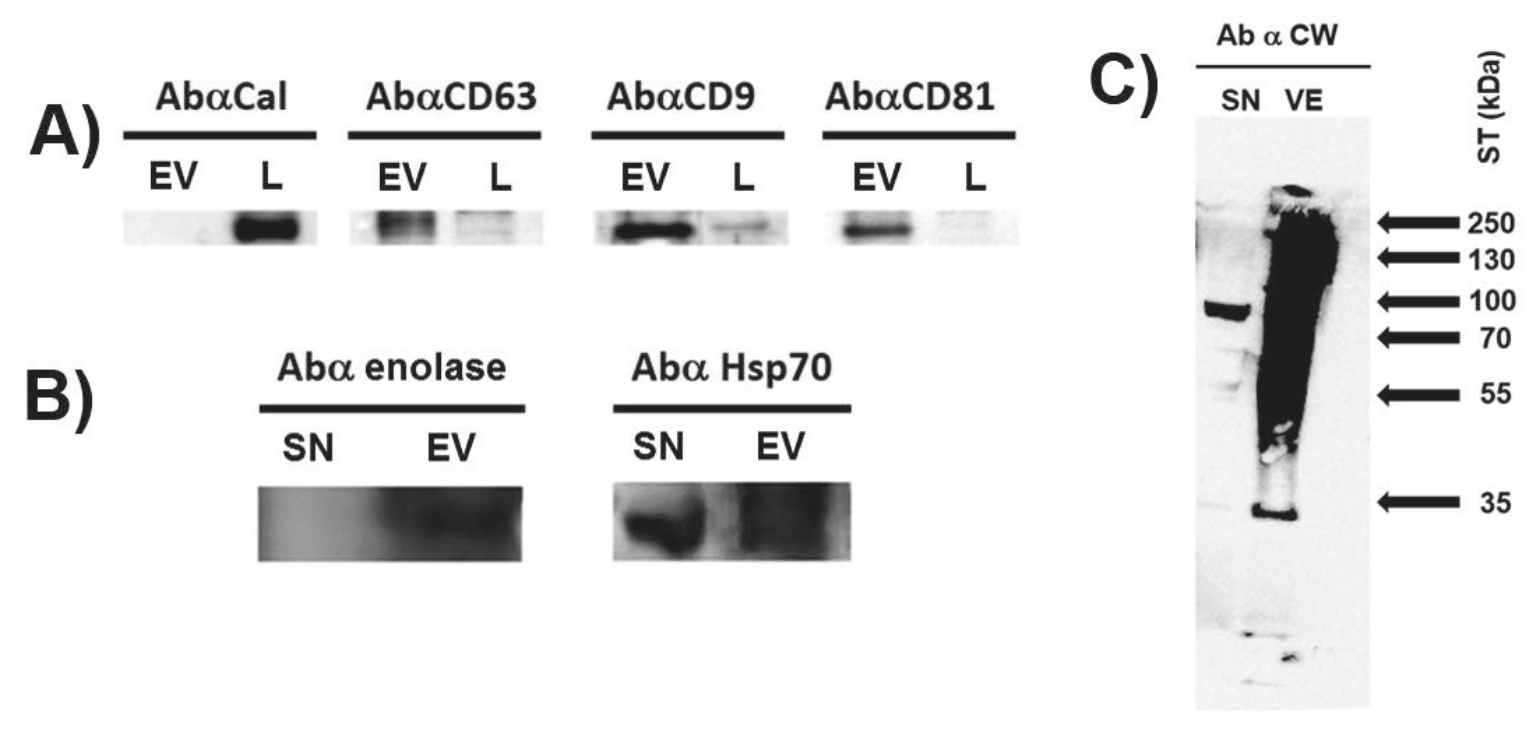

Fig. 2. Results corresponding to the Western blot performed in samples of exosomes of C. albicans using:

A) Anti-Calnexin, anti-CD63, anti-CD9 and anti-CD81 antibodies in samples of EV and their corresponding (L).

B) Anti-enolase, and anti-Hsp70 antibodies in samples of EV and their corresponding SN. C) Positive result with high polydispersity of the EV fraction versus the anti-Candida cell wall antibodies.

Tetraspanins such as CD9, CD63 and CD81, are considered to be biomarkers of extracellular vesicles by several authors [23-26]. The positive result in the EV fraction and their absence in the cell lysate ensures the purity of the obtained exosomes and the absence of cellular contaminants. Calnexin (a protein located in the endoplasmic reticulum) is not detected in EV sample, while it is clearly present in cell lysate fractions. This allows ratifying the results obtained with tetraspanins about the purity of the obtained exosomes and the absence of possible contamination with cellular fragments.

Purified exosomes were also tested for presence of mannoproteins; in order to achieve this we treated exosomes samples with Concanavalin A-ferritin. Transmission electron microscope images show black dotted spots inside the vesicles (Fig 1E), not observed in not treated samples (figure 1A), which indicates the presence of mannoproteins in the microvesicles and confirms the results obtained by WB of microvesicles proteins detected with anti-mannan (anti-Candida cell wall) antibodies (figure 2C). 
The method developed introduces modifications to previous protocols to purify yeast microvesicles/exosomes which are free of pollution cytoplasmic contamination that might interfere with following studies to determine its protein composition and the role that these vesicles can play.

\section{Transparency declarations}

None to declare.

\section{Financing}

This work was partially supported by grant PI12/01797, MINECO integrated in the "Fondo Europeo de Desarrollo Regional (FEDER)", and cofinanced by Instituto de Salud Carlos III (ISCIII).

\section{Acknowledgments}

J. A. Castillo-Garit thanks the program "Estades Temporals per a Investigadors Convidats" for a fellowship to work at the University of Valencia in 2018.

\section{Conflict of interest}

The authors declare that they have no conflict of interest.

\section{LITERATURE CITED}

[1] Beck-Sague C, Jarvis WR. Secular trends in the epidemiology of nosocomial fungal infections in the United States, 1980-1990. National Nosocomial Infections Surveillance System. The Journal of infectious diseases. 1993;167(5):1247-51.

[2] Hsueh PR, Graybill JR, Playford EG, Watcharananan SP, Oh MD, Ja'alam K, et al. Consensus statement on the management of invasive candidiasis in Intensive Care Units in the Asia-Pacific Region. International journal of antimicrobial agents. 2009;34(3):205-9.

[3] Mean M, Marchetti O, Calandra T. Bench-to-bedside review: Candida infections in the intensive care unit. Critical care (London, England). 2008;12(1):204.

[4] Ajenjo HM, Aquevedo SA, Guzman DA, Poggi MH, Calvo AM, Castillo VC, et al. [Epidemiologial profile of invasive candidiasis in intensive care units at a university hospital]. Revista chilena de infectologia : organo oficial de la Sociedad Chilena de Infectologia. 2011;28(2):118-22.

[5] Pfaller MA, Diekema DJ. Epidemiology of invasive candidiasis: a persistent public health problem. Clinical microbiology reviews. 2007;20(1):133-63. 
[6] Nanjappa S, Kynaston K, Moreland S, Carraway S, Sandin RL, Jani D, et al. Candidemia in Cancer Patients: A Retrospective Analysis; 2001-20142015.

[7] Bennett JE. 257 - Introduction to Mycoses. In: Bennett JE, Dolin R, Blaser MJ, editors. Mandell, Douglas, and Bennett's Principles and Practice of Infectious Diseases (Eighth Edition). Philadelphia: Content Repository Only; 2015. p. 2874-8.

[8] Corry DB, Ampel NM, Christian L, Locksley RM, Galgiani JN. Cytokine Production by Peripheral Blood Mononuclear Cells in Human Coccidioidomycosis. The Journal of infectious diseases. 1996;174(2):440-3.

[9] Vazquez JA, Beckley A, Sobel JD, Zervos MJ. Comparison of restriction enzyme analysis and pulsed-field gradient gel electrophoresis as typing systems for Candida albicans. Journal of clinical microbiology. 1991;29(5):962-7.

[10] Mayer FL, Wilson D, Hube B. Candida albicans pathogenicity mechanisms 2013.

[11] Batanghari JW, Deepe GS, Jr., Di Cera E, Goldman WE. Histoplasma acquisition of calcium and expression of CBP1 during intracellular parasitism. Molecular microbiology. 1998;27(3):531-9.

[12] Kmetzsch L, Staats CC, Rodrigues ML, Schrank A, Vainstein MH. Calcium signaling components in the human pathogen: Cryptococcus neoformans. Communicative \& integrative biology. 2011;4(2):186-7.

[13] Rodrigues ML, Nimrichter L, Oliveira DL, Nosanchuk JD, Casadevall A. Vesicular Trans-Cell Wall Transport in Fungi: A Mechanism for the Delivery of Virulence-Associated Macromolecules? Lipid insights. 2008;2:27-40.

[14] Albuquerque PC, Nakayasu ES, Rodrigues ML, Frases S, Casadevall A, Zancope-Oliveira RM, et al. Vesicular transport in Histoplasma capsulatum: an effective mechanism for trans-cell wall transfer of proteins and lipids in ascomycetes. Cellular microbiology. 2008;10(8):1695-710.

[15] Gehrmann U, Qazi KR, Johansson C, Hultenby K, Karlsson M, Lundeberg L, et al. Nanovesicles from Malassezia sympodialis and host exosomes induce cytokine responses--novel mechanisms for host-microbe interactions in atopic eczema. PloS one. 2011;6(7):e21480.

[16] Vallejo MC, Matsuo AL, Ganiko L, Medeiros LC, Miranda K, Silva LS, et al. The pathogenic fungus Paracoccidioides brasiliensis exports extracellular vesicles containing highly immunogenic alpha-Galactosyl epitopes. Eukaryotic cell. 2011;10(3):343-51.

[17] Thery C. Exosomes: secreted vesicles and intercellular communications. F1000 biology reports. 2011;3:15.

[18] Oliveira DL, Nakayasu ES, Joffe LS, Guimaraes AJ, Sobreira TJ, Nosanchuk JD, et al. Biogenesis of extracellular vesicles in yeast: Many questions with few answers. Communicative \& integrative biology. 2010;3(6):533-5.

[19] Bradford MM. A rapid and sensitive method for the quantitation of microgram quantities of protein utilizing the principle of protein-dye binding. Analytical Biochemistry. 1976;72(1):248-54.

[20] Laemmli UK. Cleavage of Structural Proteins during the Assembly of the Head of Bacteriophage T4. Nature. 1970;227:680.

[21] Towbin H, Staehelin T, Gordon J. Electrophoretic transfer of proteins from polyacrylamide gels to nitrocellulose sheets: procedure and some applications. Proceedings of the National Academy of Sciences of the United States of America. 1979;76(9):4350-4. 
[22] Burnette WN. "Western blotting": electrophoretic transfer of proteins from sodium dodecyl sulfate-polyacrylamide gels to unmodified nitrocellulose and radiographic detection with antibody and radioiodinated protein A. Anal Biochem. 1981;112(2):195-203.

[23] Kumar D, Gupta D, Shankar S, Srivastava RK. Biomolecular characterization of exosomes released from cancer stem cells: Possible implications for biomarker and treatment of cancer. Oncotarget. 2015;6(5):3280-91.

[24] Daaboul GG, Gagni P, Benussi L, Bettotti P, Ciani M, Cretich M, et al. Digital Detection of Exosomes by Interferometric Imaging. Scientific reports. 2016;6:37246.

[25] Deregibus MC, Figliolini F, D’Antico S, Manzini PM, Pasquino C, De Lena M, et al. Chargebased precipitation of extracellular vesicles. International journal of molecular medicine. 2016;38(5):1359-66.

[26] Yuan Z, Kolluri KK, Gowers KH, Janes SM. TRAIL delivery by MSC-derived extracellular vesicles is an effective anticancer therapy. Journal of extracellular vesicles. 2017;6(1):1265291. 